\title{
CORRECTION
}

Open Access

\section{Correction to: Climate factors influencing effective use of geothermal resources in SE Poland: the Lublin trough}

\author{
${\text { Bartłomiej Ciapała }{ }^{1 *} \mathbb{C} \text {, Jakub Jurasz }{ }^{1,2,3}, \text { Mirosław Janowski }^{1} \text { and Beata Kępińska }}^{4}$
}

The original article can be found online at https://doi. org/10.1186/s40517-02100184-1.

\section{*Correspondence:}

bciapala@agh.edu.pl

${ }^{1}$ AGH University of Science and Technology, Kraków,

Poland

Full list of author information

is available at the end of the article

\section{Correction to: Geotherm Energy (2021) 9:1 \\ https://doi.org/10.1186/s40517-021-00184-1}

The original version of this (Ciapała et al. 2021) article was published with incorrect reference citations because of production errors.

The supplementary file which was missed out in the original version was also provided in this Correction article. The original article has been corrected.

\section{Supplementary Information}

The online version contains supplementary material available at https://doi.org/10.1186/s40517-021-00202-2.

Additional file 1. Time laps of expected heat demand changes over years 2005-2007.

\section{Author details}

${ }^{1}$ AGH University of Science and Technology, Kraków, Poland. ${ }^{2}$ School of Business, Society and Engineering, Mälardalens Högskola, 72113 Västerås, Sweden. ${ }^{3}$ Faculty of Environmental Engineering, Wroclaw University of Science and Technology, 50-370 Wroclaw, Poland. ${ }^{4}$ Instytut Gospodarki Surowcami Mineralnymi I Energią PAN, Kraków, Poland.

Published online: 04 October 2021

Reference

Ciapała B, Jurasz J, Janowski M, Kępińska B. Climate factors influencing effective use of geothermal resources in SE Poland: the Lublin trough. Geotherm Energy. 2021;9(1):1-6.

Publisher's Note

Springer Nature remains neutral with regard to jurisdictional claims in published maps and institutional affiliations. author(s) and the source, provide a link to the Creative Commons licence, and indicate if changes were made. The images or other third party material in this article are included in the article's Creative Commons licence, unless indicated otherwise in a credit line to the material. If material is not included in the article's Creative Commons licence and your intended use is not permitted by statutory regulation or exceeds the permitted use, you will need to obtain permission directly from the copyright holder. To view a copy of this licence, visit http:// creativecommons.org/licenses/by/4.0/. 